\section{Growth and Yield of Watermelon on Polyethylene Mulch with Different Spacings and Nitrogen Rates}

\author{
Smiljana Goreta, ${ }^{1}$ Slavko Perica, Gvozden Dumicic, Lovre Bucan, and \\ Katja Zanic \\ Institute for Adriatic Crops, Put duilova 11, Split 21000, Croatia
}

Additional index words. Citrullus lanatus, ammonium nitrate, fertigation, planting density, fruit size

\begin{abstract}
Suggested watermelon planting densities and $\mathbf{N}$ rates vary on a large scale, indicating that there is insufficient knowledge about their effects. Therefore, the objective of this study was to evaluate the effects of $N$ rate and planting density on growth, yield and quality of watermelon [Citrullus lanatus (Thunb.) Matsum \& Nakai] grown on black polyethylene mulch. The field experiments with 'Crimson Sweet' watermelon were conducted in two climatologically different growing regions. The treatments were factorial combinations of three in-row plant spacings $(0.5,1.0$, and $1.5 \mathrm{~m})$ and three $\mathrm{N}$ rates $(115$, 195 , and $\left.275 \mathrm{~kg} \cdot \mathrm{ha}^{-1}\right)$. Part of the $N\left(35 \mathrm{~kg} \cdot \mathrm{ha}^{-1}\right)$ was applied preplant and the remainder was fertigated. Vine length increased linearly up to 7 weeks after planting (WAP) as $\mathbf{N}$ rate increased from 115 to $275 \mathrm{~kg} \cdot \mathrm{ha}^{-1}$, and up to 9 WAP as plant spacing increased from 0.5 to $1.5 \mathrm{~m}$. Total and marketable yields per ha or per plant did not increase with $\mathrm{N}$ rates above $115 \mathrm{~kg} \cdot \mathrm{ha}^{-1}$. Average fruit weight and fruit size distribution were generally unaffected by $N$ rate. Leaf $N$ concentration increased as $N$ rate increased, although leaf $\mathrm{N}$ concentrations at the lowest $\mathrm{N}$ rate $\left(115 \mathrm{~kg} \cdot \mathrm{ha}^{-1}\right)$ even at 9 WAP were relatively high (43.3 to $47.3 \mathrm{~g} \cdot \mathrm{kg}^{-1}$ ). Total and marketable yields per ha were linearly decreased with an increase in plant spacing from 0.5 to $1.5 \mathrm{~m}$, and the same was noticed with the total and marketable number of fruit per ha. With increased plant spacing average fruit weight increased and fruit size distribution shifted to larger categories.
\end{abstract}

The global consumption of watermelon [Citrullus lanatus (Thunb.) Matsum \& Nakai] is greater than that of any other cucurbit (Robinson and Decker-Walters, 1997), its world production has expanded from 2.9 to $3.7 \times 10^{6}$ ha in the period from 1999 to 2003 (Faostat data, 2004).

Enhanced earliness and yield in watermelon crop has been achieved through improvement of cultural practices (Lu et al., 2003; Soltani et al., 1995). Many commercial vegetable producers use mulching and drip irrigation as a common practice. Both technologies have been developed to enhance crop growth and improve water use efficiency (Brinen et al., 1979; Elmstrom et al., 1981). Improved N fertigation efficiency (Hochmuth, 2003) and decreased N leaching have also been noted (Pier and Doerge, 1995a; Romic et al., 2003).

Nitrogen has been frequently recognized as a major factor affecting watermelon yield. However, the suggested rates varied considerably. Srinivas et al. (1989) found that N up to $120 \mathrm{~kg} \cdot \mathrm{ha}^{-1}$ increased fruit yield, whereas

Received for publication 5 July 2004. Accepted for publication 3 Sept. 2004. The authors gratefully acknowledge Agricultural Research Council of Croatia (grant no. 525-02-98-25) for financial support and Zed Rengel for critical review of this manuscript. Mention of a trademark, proprietary product, or vendor does not constitute a guarantee or warranty of the product by the U.S. Dept. of Agriculture and does not imply its approval to the exclusion of other products or vendors that also may be suitable.

${ }^{1}$ To whom reprint request should be addressed; emailsmilja@krs.hr.
Hochmuth and Cordasco (2000) who reviewed watermelon response to $\mathrm{N}$, found that in majority of trials optimum yields were achieved with $\mathrm{N}$ rates from 134 to $145 \mathrm{~kg} \cdot \mathrm{ha}^{-1}$. In arid region maximum yields were obtained with the $\mathrm{N}$ application as high as 220 to $300 \mathrm{~kg} \cdot \mathrm{ha}^{-1}$ (Pier and Doerge, 1995b).

Competition for water and nutrients in dense plant stands might be responsible for the decrease in plant growth and yield (Knavel, 1988). Generally, in watermelon the yield and number of fruit per unit area increase with increased crop density, whereas the yield and number of fruit per plant decrease (Brinen et al., 1979; Duthie et al., 1999a, 1999b; Motsenbocker and Arancibia, 2002; NeSmith, 1993; Sanders et al., 1999; Srinivas et al., 1989). The increased number of fruit per area is probably the yield component mostly contributing to a greater yield under high planting density (Duthie et al., 1999a; NeSmith, 1993). However, some studies showed that average fruit weight decreases with increasing plant density (Brinen et al., 1979; Motsenbocker and Arancibia, 2002; Sanders et al., 1999).

The impact of both $\mathrm{N}$ rate and plant density on watermelon yield has been reported in the literature frequently, yet there is insufficient knowledge about their interaction, especially when $\mathrm{N}$ fertigation is used. It is likely that optimal $\mathrm{N}$ rate would differ for different watermelon planting densities, and that $\mathrm{N}$ rate would also influence fruit quality. Therefore, the objective of this study was to evaluate the effects of $\mathrm{N}$ rate and planting density on growth, yield and quality of watermelon.
The field experiments with 'Crimson Sweet' watermelon (Clause Semences, Bretigny sur Orge, France) were conducted in two climatologically different growing regions, which represent the most important watermelongrowing areas in Croatia: Imotski $\left(43^{\circ} 15^{\prime} \mathrm{N}\right.$, $\left.17^{\circ} 14^{\prime} \mathrm{E}\right)$ with sub-Mediterranean to temperate climate, and Split $\left(43^{\circ} 30^{\prime} \mathrm{N}, 16^{\circ} 30^{\prime} \mathrm{E}\right)$ with a prevailing Mediterranean climate.

The experiments were carried out at Imotski location in 2000 and 2001, on an anthropogenic clayey eutric soil derived from colluvial brown soil on limestone ( $\mathrm{pH}$ in water 7.6, organic matter $\left.21 \mathrm{~g} \cdot \mathrm{kg}^{-1}\right)$. The experiment at Split location was conducted in 2001, on an anthropogenic, carbonate, deep clay-loamy soil on sandstone and marly soil ( $\mathrm{pH}$ in water 8.1 , organic matter $\left.26 \mathrm{~g} \cdot \mathrm{kg}^{-1}\right)$.

Watermelon seeds were sown in trays of cell volume $100 \mathrm{~cm}^{3}$, filled with the commercial substrate (Gebr. Brill Substrate GmbH \& Co. $\mathrm{KG}$, Georgsdorf, Germany). The transplants were grown in a heated greenhouse in Split and transferred just before planting to experimental sites. Planting at Imotski was carried out on 16 May 2000 and 10 May 2001. In Split, planting was done on 2 May 2001. Chlorpyrifos [O,O-diethyl O-(3,5,6-trichloro-2-pyridyl) phosphorothioate] was incorporated together with preplant fertilizer into the top $0.3 \mathrm{~m}$ of the soil at all sites.

The treatments were factorial combinations of three plant densities $(3333,5000$ or 10000 plants/ha) and three $\mathrm{N}$ rates $(115,195$, or 275 $\mathrm{kg} \cdot \mathrm{ha}^{-1}$ ) arranged in randomized complete block design with five replications. The rows were $2.0 \mathrm{~m}$ apart, and in-row plant spacing was $0.5,1.0$, or $1.5 \mathrm{~m}$.

The $35 \mathrm{~kg} \cdot \mathrm{ha}^{-1} \mathrm{~N}$ was preplant applied as fertilizer $5 \mathrm{~N}-8.7 \mathrm{P}-24.9 \mathrm{~K}$ at $700 \mathrm{~kg} \cdot \mathrm{ha}^{-1}$ at all sites and experimental treatments. Remaining $\mathrm{N}\left(80,160\right.$ and $\left.240 \mathrm{~kg} \cdot \mathrm{ha}^{-1}\right)$ for the three $\mathrm{N}$ treatments was fertigated in the form of ammonium-nitrate $(35 \% \mathrm{~N})$ in four applications. The first application (I) was 7 to $10 \mathrm{~d}$ after planting, second (II) at the early runner phase, third (III) when the diameter of fruit was about $50 \mathrm{~mm}$, and fourth (IV) when $10 \%$ of fruit reached the full size. To achieve targeted levels of $\mathrm{N}$, the fertigation was scheduled as follows: in treatment with $\mathrm{N}$ at $80 \mathrm{~kg} \cdot \mathrm{ha}^{-1}$, the 20,40 , 20 , and $0 \mathrm{~kg} \cdot \mathrm{ha}^{-1}$ were applied in the I, II, III and IV fertigation, respectively. Likewise, in treatment with $\mathrm{N}$ at $160 \mathrm{~kg} \cdot \mathrm{ha}^{-1}$ total amount of $\mathrm{N}$ was split into $20,80,30$, and $30 \mathrm{~kg} \cdot \mathrm{ha}^{-1}$, whereas in treatment with $\mathrm{N}$ at $240 \mathrm{~kg} \cdot \mathrm{ha}^{-1}$, the $40,120,40$, and $40 \mathrm{~kg} \cdot \mathrm{ha}^{-1}$ were applied in the I, II, III and IV fertigation, respectively.

The transplants with two to three completely developed leaves were hand planted on black polyethylene mulch (thickness 0.07 $\mathrm{mm}$; width $120 \mathrm{~cm}$ ). The drip irrigation tapes (T-Systems International, San Diego, Calif.) were installed near the center of the row, and plants were irrigated as needed. Weeds between rows were removed by hand if necessary, while pests and disease were controlled according to common practices.

The length of the most developed vine 
was measured 4, 7 and 9 weeks after planting (WAP) and number of branches ticker than 5 mm was counted four WAP. All measurements were taken on a subsample of five plants per plot. The most recently fully expanded leaves (blades plus petiole, about 5 th leaf from the tip) were collected 4,7 , and 9 WAP. In the collected samples, leaf $\mathrm{N}$ was determined by Kjeldahl digestion using a Kjeltec System 1026 (Tecator, 1987). Melons were harvested as fruit ripened, and each fruit from all plants was weighed. The fruit smaller than $4.5 \mathrm{~kg}$ were considered non-marketable. According to this, the total and marketable yields as well as the total and marketable number of fruit per plant and per area were calculated. The total soluble solids content was determined from juice obtained from the fruit heart section using a hand refractometer (Kruss Optronic $\mathrm{GmbH}$ ); one representative melon was measured per plot in the main harvest.

The data were analyzed separately for each year and location combination due to significant influence of the environment on examined traits. Analysis of variance (ANOVA) was carried out using proc GLM of the SAS software package (SAS Institute, 1989) to determine the significance of $\mathrm{N}$ rate and plant spacings main effects and presence of interaction between $\mathrm{N}$ rate and spacing. There was no significant interaction in any of observed traits, so the linear and quadratic contrasts were used to analyze main effects of $\mathrm{N}$ rate and spacing.

\section{Results and Discussion}

Vegetative growth and leaf $N$ concentration. Vine length increased linearly with an increase in $\mathrm{N}$ rate from 115 to $275 \mathrm{~kg} \cdot \mathrm{ha}^{-1}$ until 7 weeks after planting (WAP) at Imotski in 2000 and until 4 WAP at Split (Table 1). An increase in plant spacing from 0.5 to 1.5 $\mathrm{m}$ resulted in linear increase of vine length until 7 WAP at Imotski in 2000 and until 9 WAP at Split (Table 1). Number of branches, measured at an early stage of plant development (4 WAP), increased linearly from 4.0 to 4.5 by increasing $\mathrm{N}$ rate from 115 to $195 \mathrm{~kg} \cdot \mathrm{ha}^{-1}$, and by increasing spacing from 0.5 to $1.0 \mathrm{~m}$ at Imotski in 2000, while further increase of $\mathrm{N}$ rate or spacing had no effect. At Split only the effect of plant spacing was significant, no. of branches linearly increased from 3.9 to 4.5 as plant spacing increased from 0.5 to $1.5 \mathrm{~m}$. No effect of treatments on vegetative growth at Imotski in 2001 was found (data not shown). There was no significant interaction between $\mathrm{N}$ and plant spacing in any of observed vegetative growth parameters.

The leaf $\mathrm{N}$ concentration generally increased as $\mathrm{N}$ rate increased at all observed phenological phases and locations (Table 2), whereas there was no influence of plant spacing on leaf $\mathrm{N}$ concentration (data not shown). At Imotski leaf $\mathrm{N}$ concentration increased linearly as $\mathrm{N}$ rate increased from 115 to $275 \mathrm{~kg} \cdot \mathrm{ha}^{-1}$ until 7 and 4 WAP in 2000 and 2001, respectively. The effect of $\mathrm{N}$ rate on leaf $\mathrm{N}$ concentration was significant throughout the sampling period at Split. Leaf N concentration measured 4 and 9 WAP at Split responded quadratically on increase of $\mathrm{N}$ rate. During the growing season leaf $\mathrm{N}$ concentration had tendency to decrease, with the lowest leaf N concentration $(P \leq 0.05)$ measured 9 WAP at both locations (Table 2). The reduction in $\mathrm{N}$ concentration as the crop progress has been already noted (Elmstrom et al., 1981; Locascio et al., 1997; Whale and

Table 1. Main effects of $\mathrm{N}$ rate and in-row plant spacing on vine length and number of branches at Imotski in 2000 and Split in 2001.

\begin{tabular}{|c|c|c|c|c|c|c|c|c|}
\hline \multirow[b]{4}{*}{ Treatment } & \multicolumn{4}{|c|}{ Imotski 2000} & \multicolumn{4}{|c|}{ Split 2001} \\
\hline & \multicolumn{3}{|c|}{ Vine length $(\mathrm{cm})$} & \multirow{3}{*}{$\begin{array}{c}\text { No. of } \\
\text { branches }\end{array}$} & \multicolumn{3}{|c|}{ Vine length $(\mathrm{cm})$} & \multirow{3}{*}{$\begin{array}{c}\text { No. of } \\
\text { branches }\end{array}$} \\
\hline & \multicolumn{3}{|c|}{ Weeks after planting } & & \multicolumn{3}{|c|}{ Weeks after planting } & \\
\hline & 4 & 7 & 9 & & 4 & 7 & 9 & \\
\hline \multicolumn{9}{|l|}{$\overline{\mathrm{N}\left(\mathrm{kg} \cdot \mathrm{ha}^{-1}\right)}$} \\
\hline 115 & 60.8 & 151.3 & 220.2 & 4.0 & 45.1 & 155.2 & 226.3 & 4.2 \\
\hline 195 & 81.6 & 169.0 & 218.3 & 4.5 & 45.8 & 158.7 & 228.4 & 4.1 \\
\hline 275 & 86.0 & 193.6 & 220.5 & 4.5 & 52.3 & 164.5 & 237.8 & 4.4 \\
\hline Significance & $\mathrm{L}^{* * *}$ & $\mathrm{~L}^{* * *}$ & NS & $\mathrm{L}^{*}$ & $\mathrm{~L}^{*}$ & NS & NS & NS \\
\hline \multicolumn{9}{|l|}{ Spacing (m) } \\
\hline 0.5 & 71.0 & 162.2 & 218.1 & 4.0 & 43.1 & 142.7 & 217.9 & 3.9 \\
\hline 1.0 & 78.0 & 172.6 & 220.2 & 4.5 & 48.3 & 152.4 & 227.4 & 4.3 \\
\hline 1.5 & 79.4 & 179.1 & 220.7 & 4.5 & 51.8 & 183.3 & 247.2 & 4.5 \\
\hline Significance & $\mathrm{L}^{*}$ & $\mathrm{~L}^{* * *}$ & NS & $\mathrm{L}^{*}$ & $\mathrm{~L}^{* *}$ & $\mathrm{~L}^{* * * *}$ & $\mathrm{~L}^{* *}$ & $\mathrm{~L}^{*}$ \\
\hline
\end{tabular}

NS,",**,****N Nonsignificant or significant at $P \leq 0.05,0.01$, or 0.001 , respectively; significant effects were linear (L).

Table 2. Main effect of N rate on leaf N concentration at Imotski in 2000 and 2001, and at Split in 2001.

\begin{tabular}{|c|c|c|c|c|c|c|c|c|c|}
\hline \multirow{4}{*}{$\begin{array}{l}\mathrm{N} \text { rate } \\
\left(\mathrm{kg} \cdot \mathrm{ha}^{-1}\right)\end{array}$} & \multicolumn{9}{|c|}{ Leaf $\mathrm{N}$ concn $\left(\mathrm{g} \cdot \mathrm{kg}^{-1}\right.$ dry wt) } \\
\hline & \multicolumn{3}{|c|}{ Imotski 2000} & \multicolumn{3}{|c|}{ Imotski 2001} & \multicolumn{3}{|c|}{ Split 2001} \\
\hline & \multicolumn{3}{|c|}{ Weeks after planting } & \multicolumn{3}{|c|}{ Weeks after planting } & \multicolumn{3}{|c|}{ Weeks after planting } \\
\hline & 4 & 7 & 9 & 4 & 7 & 9 & 4 & 7 & 9 \\
\hline 115 & --- & 48.9 & 43.6 & 57.5 & 55.2 & 47.3 & 49.3 & 49.3 & 43.3 \\
\hline 195 & --- & 52.2 & 43.4 & 59.9 & 54.7 & 48.2 & 52.6 & 54.6 & 48.9 \\
\hline 275 & --- & 53.4 & 44.4 & 60.8 & 56.3 & 48.5 & 51.2 & 55.2 & 46.9 \\
\hline Significance & --- & $\mathrm{L}^{* * * *}$ & NS & $\mathrm{L}^{*}$ & NS & NS & $\mathrm{Q}^{*}$ & $\mathrm{~L}^{* *}$ & $\mathrm{Q}^{* *}$ \\
\hline
\end{tabular}

$\widehat{\mathrm{NS}, * * *, * * * *}$ Nonsignificant or significant at $P \leq 0.05,0.01$, or 0.001 , respectively; significant effects were linear (L) or quadratic (Q).

Table 3. Main effects of N rate and in-row plant spacing on yield and number of fruit per ha at Imotski in 2000 and 2001 , and at Split in 2001.

\begin{tabular}{|c|c|c|c|c|c|c|c|c|c|c|c|c|}
\hline \multirow[b]{3}{*}{ Treatment } & \multicolumn{4}{|c|}{ Imotski, 2000} & \multicolumn{4}{|c|}{ Imotski, 2001} & \multicolumn{4}{|c|}{ Split, 2001} \\
\hline & \multicolumn{2}{|c|}{$\begin{array}{l}\text { Yield } \\
\left(\mathrm{t} \cdot \mathrm{ha}^{-1}\right)\end{array}$} & \multicolumn{2}{|c|}{$\begin{array}{l}\text { No. of fruit } \\
(1000 \mathrm{~s}) / \mathrm{ha}\end{array}$} & \multicolumn{2}{|c|}{$\begin{array}{l}\text { Yield } \\
\left(\mathrm{t} \cdot \mathrm{ha}^{-1}\right)\end{array}$} & \multicolumn{2}{|c|}{$\begin{array}{l}\text { No. of fruit } \\
(1000 \mathrm{~s}) / \mathrm{ha}\end{array}$} & \multicolumn{2}{|c|}{$\begin{array}{c}\text { Yield } \\
\left(\mathrm{t} \cdot \mathrm{ha}^{-1}\right)\end{array}$} & \multicolumn{2}{|c|}{$\begin{array}{l}\text { No. of fruit } \\
(1000 \mathrm{~s}) / \mathrm{ha}\end{array}$} \\
\hline & Total & Marketable & Total & $\overline{\text { Marketable }}$ & Total & $\overline{\text { Marketable }}$ & Total & $\overline{\text { Marketable }}$ & Total & $\overline{\text { Marketable }}$ & Total & Marketable \\
\hline \multicolumn{13}{|l|}{$\overline{\mathrm{N}\left(\mathrm{kg} \cdot \mathrm{ha}^{-1}\right)}$} \\
\hline 115 & 38.9 & 35.0 & 6.12 & 5.00 & 42.9 & 32.1 & 7.61 & 5.03 & 81.9 & 77.3 & 9.87 & 8.16 \\
\hline 195 & 38.0 & 31.6 & 6.64 & 4.84 & 37.1 & 32.9 & 7.23 & 5.16 & 81.8 & 77.0 & 9.76 & 8.52 \\
\hline 275 & 36.7 & 29.4 & 6.92 & 4.71 & 35.6 & 22.1 & 7.00 & 3.65 & 81.8 & 75.5 & 10.04 & 8.37 \\
\hline Significance & NS & $\mathrm{L}^{*}$ & NS & NS & $\mathrm{L}^{* * * *}$ & $\mathrm{~L}^{* * * *}$ & $\mathrm{~L}^{* *}$ & $\mathrm{~L}^{* * * *}$ & NS & NS & NS & NS \\
\hline \multicolumn{13}{|l|}{ Spacing (m) } \\
\hline 0.5 & 51.7 & 41.4 & 9.43 & 6.53 & 58.0 & 44.0 & 11.63 & 7.13 & 103.8 & 95.3 & 13.44 & 11.21 \\
\hline 1.0 & 33.5 & 29.3 & 5.50 & 4.33 & 34.5 & 25.6 & 6.13 & 4.00 & 80.4 & 75.9 & 9.27 & 8.07 \\
\hline 1.5 & 28.4 & 25.3 & 4.76 & 3.68 & 23.2 & 17.5 & 4.09 & 2.71 & 61.2 & 58.6 & 6.96 & 5.77 \\
\hline Significance & $\mathrm{L}^{* * * *}$ & $\mathrm{~L}^{* * * *}$ & $\mathrm{~L}^{* * * *}$ & $\mathrm{~L}^{* * *}$ & $\mathrm{~L}^{* * * *}$ & $\mathrm{~L}^{* * * *}$ & $\mathrm{~L}^{* * * *}$ & $\mathrm{~L}^{* * *}$ & $\mathrm{~L}^{* * * *}$ & $\mathrm{~L}^{* * * *}$ & $\mathrm{~L}^{* * * *}$ & $\mathrm{~L}^{* * * *}$ \\
\hline
\end{tabular}

NS,******** Nonsignificant or significant at $P \leq 0.05,0.01$, or 0.001 , respectively; significant effects were linear (L). 
Table 4. Main effects of $\mathrm{N}$ rate and in-row plant spacing on yield and number of fruit per plant, fruit weight and soluble solids at Imotski in 2000 and 2001 , and at Split in 2001.

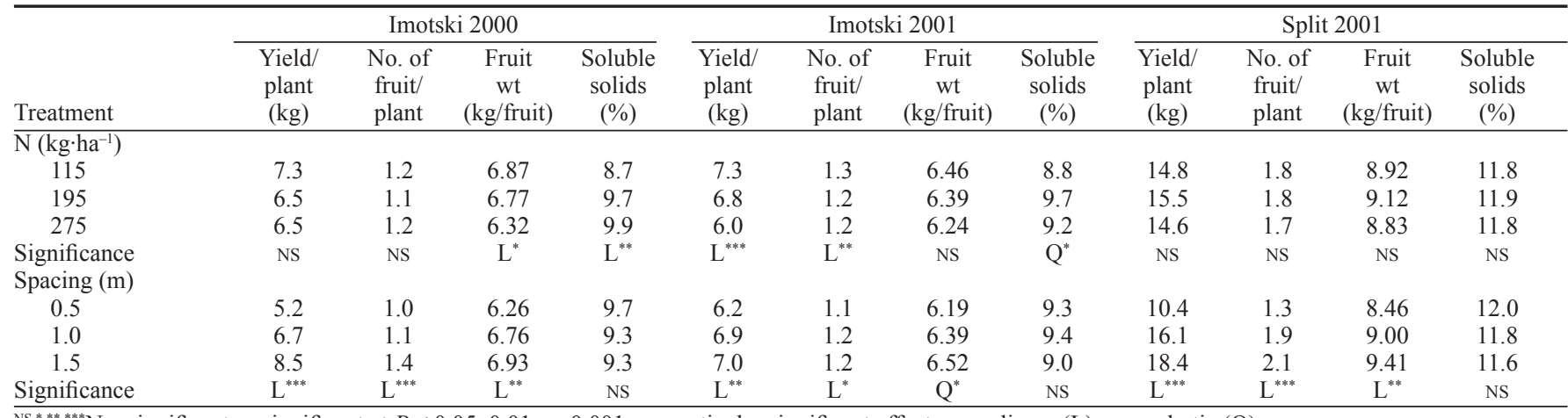

$\widehat{\mathrm{NS}^{*}, * *, * * * *}$ Nonsignificant or significant at $P \leq 0.05,0.01$, or 0.001 , respectively; significant effects were linear (L) or quadratic (Q).

Table 5. Effect of in-row plant spacing on fruit size category expressed as a percent of total number of fruit at Imotski in 2000 and 2001 , and at Split in 2001.

\begin{tabular}{|c|c|c|c|c|c|c|c|c|c|c|}
\hline \multirow[b]{3}{*}{$\begin{array}{l}\text { Spacing } \\
(\mathrm{m})\end{array}$} & \multicolumn{10}{|c|}{ Fruit size ${ }^{\mathrm{z}}(\%$ of no. of fruit) } \\
\hline & \multicolumn{5}{|c|}{ Imotski 2000} & \multicolumn{5}{|c|}{ Split 2001} \\
\hline & $\begin{array}{l}\text { Extra } \\
\text { small }\end{array}$ & Small & Medium & Large & $\begin{array}{l}\text { Extra } \\
\text { large }\end{array}$ & $\begin{array}{l}\text { Extra } \\
\text { small }\end{array}$ & Small & Medium & Large & $\begin{array}{l}\text { Extra } \\
\text { large }\end{array}$ \\
\hline 1.0 & 23 & 24 & 39 & 13 & 1 & 11 & 13 & 24 & 26 & 26 \\
\hline 1.5 & 20 & 25 & 37 & 15 & 3 & 15 & 14 & 21 & 18 & 32 \\
\hline Significance & $\mathrm{L}^{*}$ & $\mathrm{~L}^{*}$ & $\mathrm{~L}^{*}$ & $\mathrm{~L}^{*}$ & NS & NS & NS & NS & $\mathrm{L}^{*}$ & $\mathrm{~L}^{*}$ \\
\hline
\end{tabular}

${ }^{2}$ Fruit size: extra-small $(<4.5 \mathrm{~kg})$; small $(4.5<6 \mathrm{~kg})$; medium $(6<8 \mathrm{~kg})$; large $(8<10 \mathrm{~kg})$; extra-large $(\geq 10 \mathrm{~kg})$.

$\mathrm{NS}, * * *, * * *^{*}$ Nonsignificant or significant at $P \leq 0.05,0.01$, or 0.001 , respectively; significant effects were linear (L).

Masiunas, 2003). The lowest leaf N concentration coincided with the fruit growth (9 WAP) perhaps indicating that $\mathrm{N}$ was remobilized for fruit development, as it was reported in some other crops (Perica, 2001; Whale and Masiunas, 2003). In comparison to optimal leaf $\mathrm{N}$ levels (Hartz and Hochmuth, 1996; Lopez-Cantarero et al., 1992), concentrations obtained in this study were at the sufficiency level even at the lowest $\mathrm{N}$ rate $\left(115 \mathrm{~kg} \cdot \mathrm{ha}^{-1}\right)$.

Yield, yield components and fruit quality. Yield and fruit weight were highly depended on the trial locations, although we have used the same cultivar and technology, and planted on similar dates. At Split, the yield and the fruit weight were higher than at Imotski (overall average 77 vs. $30 \mathrm{t} \cdot \mathrm{ha}^{-1}$ and 9 vs. $6 \mathrm{~kg} /$ fruit, respectively). At Imotski in 2000 the summer was extremely hot with unfavorable conditions for watermelon growth and development. In the second year (Imotski 2001) there was a strong attack of twospotted spider mite (Tetranychus urticae). In contrast, the experiment at the Split location was carried out without special problems.

The marketable yields per ha were significantly reduced with an increase in $\mathrm{N}$ rate from 115 to $275 \mathrm{~kg} \cdot \mathrm{ha}^{-1}$ at Imotski in 2000 and 2001, whereas total yield and total and marketable number of fruit per ha were significantly reduced only at Imotski in 2001 (Table 3). At the same location in 2001 the yield and number of fruit per plant were linearly reduced with an increase of N rate (Table 4). There was no effect of $\mathrm{N}$ rate on yield and number of fruit per ha or per plant at Split (Tables 3 and 4).

In contrast to earlier findings (Hochmuth and Cordasco, 2000; Pier and Doerge, 1995b; Srinivas et al., 1989) in our study fruit yield did not increase with $\mathrm{N}$ rates above $115 \mathrm{~kg} \cdot \mathrm{ha}^{-1}$. Also, leaf $\mathrm{N}$ concentrations at the lowest $\mathrm{N}$ rate $\left(115 \mathrm{~kg} \cdot \mathrm{ha}^{-1}\right)$ even at nine WAP were relatively high ( 43.3 to $47.3 \mathrm{~g} \cdot \mathrm{kg}^{-1}$ ). This indicates that during the plant growth considerable $\mathrm{N}$ was available to plants even at the lowest $\mathrm{N}$ rate. We assume that total and marketable yields achieved at the lowest $\mathrm{N}$ rate in the present study were partly the result of splitting $\mathrm{N}$ application, which may have enabled better use of the given $\mathrm{N}$ rate as it was found on tomato (Locascio et al., 1997) and strawberry (Hochmuth et al., 1996). We suppose that water and $\mathrm{N}$ distribution pattern as well as watermelon root development under drippers are factors strongly affecting those findings. In addition, obtained yield at the lowest $\mathrm{N}$ rate in our study also indicates that the soil was releasing considerable amount of $\mathrm{N}$. The idea of a part of $\mathrm{N}$ being derived from decomposition of soil organic matter is supported by soil conditions (organic matter $>20 \mathrm{~g}^{\mathrm{kg}} \mathrm{kg}^{-1}$ ), and high temperature and humidity bellow the black mulch throughout the growing season.

As in the case of vegetative parameters, there was no interaction between $\mathrm{N}$ and plant spacings on yield and yield components. The total and marketable yields per ha were linearly decreased with an increase in plant spacing from 0.5 to $1.5 \mathrm{~m}$, and the same was noticed with the total and marketable number of fruit per ha at both locations (Table 3 ). On contrary with an increase in plant spacing from 0.5 to 1.5 the yield and number of fruit per plant linearly increased (Table 4). This relationship has been frequently noted (Brinen et al., 1979; Duthie et al., 1999a, 1999b; Motsenbocker and Arancibia, 2002; NeSmith, 1993; Sanders et al., 1999; Srinivas et al., 1989), however the magnitude of response varied widely.

The average marketable fruit weight in this study ranged from 6.19 to $9.41 \mathrm{~kg}$ (Table 4). The differences were mostly caused by experi- mental site and spacing. Nitrogen had little or no effect except at Imotski in 2000 where the fruit weight was linearly decreased from 6.87 to $6.32 \mathrm{~kg} /$ fruit with an increase in $\mathrm{N}$ rate from 115 to $275 \mathrm{~kg} \cdot \mathrm{ha}^{-1}$. At both locations the fruit weight was increased with an increase in plant spacing from 0.5 to $1.5 \mathrm{~m}$ (Table 4).

Besides the simple distinction between marketable (fruit $\geq 4.5 \mathrm{~kg}$ ) and non marketable yield (fruit $<4.5 \mathrm{~kg}$ ), farmers are interested in fruit of certain size due to better price achieved for fruit in particular category. Even though different $\mathrm{N}$ fertilization did not have any effect on fruit size distribution (data not shown), plant spacing affected it significantly (Table 5). At Imotski in 2000, the highest percentage of fruit was in the categories extra small (31\%) and small $(33 \%)$ at $0.5 \mathrm{~m}$ (Table 5), whereas at 1 and $1.5 \mathrm{~m}$ the highest percentage of fruit was in the category medium (39\% and $37 \%$ ). Consequently, with an increase of plant spacing the percentage of fruit in small categories decreased. At Split, planting density did not affect percentage of fruit in the categories below large. However, at $0.5 \mathrm{~m}, 24 \%$ of the fruit were in large and $19 \%$ in extra large category, whereas at $1.5 \mathrm{~m}, 18 \%$ and $32 \%$ of the fruit were in those two categories (Table 5). The plant spacing had no effect on fruit size distribution at Imotski in 2001 (data not shown). The impact of plant spacing on fruit size distribution is still matter of discussion. NeSmith (1993) reported that fruit weight distribution was not influenced by plant spacing. However, other results (Motsenbocker and Arancibia, 2002) support the idea of fruit size categories being dependent on plant spacing.

Content of soluble solids was increased as $\mathrm{N}$ rate increased at Imotski in both years (Table 4). This could be the result of ion accumulation in soil under higher $\mathrm{N}$ rates (195 
and $\left.275 \mathrm{~kg} \cdot \mathrm{ha}^{-1}\right)$, considering that salinity could increase the percentage of soluble solids (del Amor et al., 1999). At Split, the soluble solid content was relatively high (on the average $11.8 \%$ ), and unaffected by the spacing or $\mathrm{N}$ rate applied (Table 4).

The lack of interactions between $\mathrm{N}$ and plant spacing is somewhat surprising because we expected such interaction to occur at least under high planting densities. However, the threshold density above which watermelon yield per area starts to decline was not reached in our study. Our results suggest that $\mathrm{N}$ fertilization rates resulting in higher than sufficient leaf $\mathrm{N}$ concentration hardly can promote the growth and yield of plants under high densities. Similarly, Srinivas et al. (1989) did not report the significant interaction between plant spacing and $\mathrm{N}$ fertilization on watermelon yield or $\mathrm{N}$ uptake. Regardless of the chosen plant spacing, it is clear that the current fertilizer guidelines for $\mathrm{N}$ developed for bare soil watermelon production cannot be used for production on polyethylene mulch with drip fertigation. Thus, the optimization of $\mathrm{N}$ fertigation for watermelon remains open. It is possible that $\mathrm{N}$ rates could be decreased further and still meet plant demands on soils like those used in this study.

Based on our data, despite the benefits in increased fruit size arising from wider spacing, the yield reduction obtained at the same density should be taken into consideration. Sanders et al. (1999) proposed that the density of around 10000 plants per ha could be used if targeted average fruit weight is above $9 \mathrm{~kg}$. Our results partly support that suggestion. Under good growing conditions, optimal water and nutrient supply (as in Split, 2001), the plant spacing of 10000 plants per ha could produce top marketable yield $\left(95.3 \mathrm{t} \cdot \mathrm{ha}^{-1}\right)$ and average fruit weight of $8.5 \mathrm{~kg}$. However, under suboptimal conditions (Imotski 2000 and 2001) planting density could be around 10000 plants per ha only if there is a market for small fruit.

\section{Literature Cited}

Brinen, G.H., S.J. Locascio, and G.W. Elmstrom 1979. Plant and row spacing, mulch, and fertilizer rate effects on watermelon production. J. Amer. Soc. Hort. Sci. 104:724-726.

del Amor, F.M., V. Martinez, and A. Cerda. 1999. Salinity duration and concentration affect fruit yield and quality, and growth and mineral composition of melon plants grown in perlite. HortScience 34:1234-1237

Duthie, J.A., B.W. Roberts, J.V. Edelson, and J.W. Shrefler. 1999a. Plant density-dependent variation in density, frequency, and size of watermelon fruits. Crop Sci. 39:412-417.

Duthie, J.A., J.W. Shrefler, B.W. Roberts, and J.V. Edelson. 1999b. Plant density-dependent variation in marketable yield, fruit biomass, and marketable fraction in watermelon. Crop Sci. 39:406-412.

Elmstrom, G.W., S.J. Locascio, and J.M. Myers. 1981. Watermelon response to drip and sprinkler irrigation. Proc. Fla. State Hort. Soc. 94:161-163.

FAOSTAT data 2004. FAO Statistical databases. Agriculture. 4 Mar. 2004. http://apps.fao.org/ faostat/default.jsp.

Hartz, T.K. and G.J. Hochmuth. 1996. Fertility management of drip-irrigated vegetables. HortTechnology 6:168-172.

Hochmuth, G.J. 2003. Progress in mineral nutrition and nutrient management for vegetable crops in the last 25 years. HortScience 38:999-1003.

Hochmuth, G.J., E.E. Albregts, C.C. Chandler, J. Cornell, and J. Harrison. 1996. Nitrogen fertigation requirements of drip-irrigated strawberries. J. Amer. Soc. Hort. Sci. 121:660-665.

Hochmuth, G. and K. Cordasco. 2000. A summary of $\mathrm{N}, \mathrm{P}$, and $\mathrm{K}$ research with watermelon in Florida. Fla. Coop. Ext. Serv. HS-755.24Aug. 2004. http: //edis.ifas. ufl.edu/ pdffiles/CV/CV23200.

Knavel, D.E. 1988. Growth, development, and yield potential of short-internode muskmelon. J.Amer Soc. Hort. Sci. 113:595-599.

Locascio, S.J., G.J. Hochmuth, F.M. Rhoads, S.M. Olson, A.G. Smajstrla, and E.A. Hanlon. 1997. Nitrogen and potassium application scheduling effects on drip-irrigated tomato yield and leaf tissue analysis. HortScience 32:230-235 .

Lopez -Cantarero, I., M. Guzman, J.L. Valenzuela, A. del Rio, and L. Romero. 1992. Variations in nutrient levels in watermelon cultivars irrigated with saline water: total ions. Commun. Soil Sci. Plant Anal. 23:2809-2822.

Lu, W., J.V. Edelson, J.A. Duthie, and B.W. Roberts. 2003. A comparison of yield between high- and low-intensity management for three watermelon cultivars. HortScience 38:351-356.

Motsenbocker, C.E. and R.A. Arancibia. 2002. Inrow spacing influences triploid watermelon yield and crop value. HortTechnology 12:437-440.

NeSmith, D.S. 1993. Plant spacing influences watermelon yield and yield components. HortScience 28:885-887.

Perica, S. 2001. Seasonal fluctuation and intracanopy variation in leaf nitrogen level in olive. J. Plant Nutr. 24:779-787.

Pier, J.W. and T.A. Doerge. 1995a. Concurrent evaluation of agronomic, economic, and environmental aspects of trickle-irrigated watermelon production. J. Environ. Qual. 24:79-86.

Pier, J.W. and T.A. Doerge. 1995b. Nitrogen and water interactions in trickle-irrigated watermelon. Soil Sci. Soc. Amer. J. 59:145-150.

Robinson, R.W and D.S. Decker-Walters. 1997. Cucurbits. CAB Intl., Wallingford, U.K.

Romic, D., M. Romic, J. Borosic, and M. Poljak. 2003. Mulching decreases nitrate leaching in bell pepper (Capsicum annuum L.) cultivation. Agr. Water Mgt. 60:87-97.

Sanders, D.C., J.D. Cure, and J.R. Schultheis. 1999. Yield response of watermelon to planting density, planting pattern, and polyethylene mulch. HortScience 34:1221-1223.

SAS Institute. 1989. SAS/STAT users' guide. ver. 6. SAS Inst., Cary, N.C.

Soltani, N., J.L. Anderson, and A.R. Hamson. 1995. Growth analysis of watermelon plants grown with mulches and rowcovers. J. Amer. Soc. Hort. Sci. 120:1001-1009.

Srinivas, K., D.M. Hegde, and G.V. Havanagi. 1989. Effect of nitrogen and plant population on yield, quality, nutrient uptake, and water use of watermelon(Citrullus lanatus Matsum et Nakai) under drip and furrow irrigation. Gartenbauwissenschaft 53:220-223.

Tecator. 1987. Determination of Kjeldahl nitrogen content with Kjeltec system 1026. Appl. Note An 86/87. Saskatoon, SK, Canada.

Whale, E.A. and J.B. Masiunas. 2003. Population density and nitrogen fertility effects on tomato growth and yield. HortScience 38:367-372. 